\title{
BIOGENIC DISSOLUTION OF A SOIL GERIUM-PHOSPHATE MINERAL
}

\author{
JAVIERA CERVINI-SILVA*†, DAVID A. FOWLE**, and JILLIAN BANFIELD*
}

ABSTRACT. The productivity of many terrestrial ecosystems is controlled or limited by phosphorus bioavailability. Within these ecosystems, nearly all of the bioavailable phosphate is ultimately derived via the weathering of apatite $\left[\mathrm{Ca}_{5}\left(\mathrm{PO}_{4}\right)_{3}(\mathrm{OH}, \mathrm{F}, \mathrm{Cl})\right]$. Highly insoluble lanthanide phosphate minerals form during apatite weathering and are important secondary phosphorus repositories in soils. Prior studies indicate that these phases can be dissolved via biologically-mediated pathways. However, mechanistic understanding of biotically- and abiotically-mediated dissolution mechanisms is lacking. We tested the impact of biogenic substances ubiquitous in soils, namely oxalate, ascorbate, citrate, and humic acids, as well as the commercial chelating agent EDTA, on the dissolution of rhabdophane $\left[\mathrm{CePO}_{4} \cdot \mathrm{H}_{2} \mathrm{O}\right]$, a representative of a large class of soil phosphate minerals. We show that these compounds can facilitate the dissolution of rhabdophane at $3<\mathrm{pH}<8$ and result in the non-stoichiometric release of $\mathrm{Ce}^{3+}{ }_{(\mathrm{aq})}$ and $\mathrm{PO}_{4}{ }^{3-}{ }_{(\mathrm{aq})}$. Release of $\mathrm{Ce}^{3+}{ }_{(\mathrm{aq})}$ and $\mathrm{PO}_{4}{ }^{3-}{ }_{(\mathrm{aq})}$ is a function of ligand type and $\mathrm{pH}$, except for EDTA, whose impact is not $\mathrm{pH}$ dependent. With the exception of oxalate reacted at $\mathrm{pH} \mathrm{3}$, the effectiveness of EDTA surpasses that of any other ligand in releasing $\mathrm{Ce}^{3+}{ }_{(\text {aq })}$ from the $\mathrm{CePO}_{4} \cdot \mathrm{H}_{2} \mathrm{O}$ surface. Speciation calculations are consistent with mineral dissolution through formation of aqueous $\mathrm{Ce}^{3+}$-EDTA complexes. Mineral dissolution in the presence of oxalate at low pH likely involves concomitant proton and ligand attack of the mineral surface. In these experiments, a fast release of $\mathrm{Ce}^{3+}{ }_{(\mathrm{aq})}$ is followed by a sharp decrease in solution $\mathrm{Ce}^{3+}{ }_{(\mathrm{aq})}$ concentration, consistent with precipitation of a Ce phase. In the presence of ligands other than EDTA and oxalate, no accumulation of $\mathrm{Ce}^{3+}$ occurred in solution due to the precipitation of $\mathrm{CeO}_{2(\mathrm{~s})}$ on the rhabdophane surface. $\mathrm{CeO}_{2}$ may be responsible for the observed oxidation of ascorbate, as it has been reported for catechol (Cervini-Silva and Banfield, 2003). Our results indicate that rhabdophane dissolution is controlled either by strong ligand complexation of $\mathrm{Ce}^{3+}{ }_{\text {aq) }}$ or by sequestration of $\mathrm{Ce}^{4+}$ ions as $\mathrm{CeO}_{2}$ (s), effectively increasing the mineral solubility. This work shows that interactions between organics, $\mathrm{CePO}_{4} \cdot \mathrm{H}_{2} \mathrm{O}$, and $\mathrm{CeO}_{2(\mathrm{~s})}$ imply potentially important linkages among the cerium, phosphorus, and organic carbon cycles in soil.

INTRODUCTION

Cerium phosphate minerals. - In near-surface, low-temperature geological settings, phosphorus is generally partitioned between the aqueous phase, organic matter, mineral surfaces, the primary phosphates such as apatite $\left[\mathrm{Ca}_{5}\left(\mathrm{PO}_{4}\right)_{3}(\mathrm{OH}, \mathrm{F}, \mathrm{Cl})\right]$, and other secondary phosphate phases (commonly trivalent metal phosphate minerals) (Taunton and others, 2000). The formation of secondary phosphate phases is often controlled and localized by the available flux of phosphate ions. For example, Banfield and Eggleton (1989) showed that lanthanides released by dissolution of granite minerals (mostly allanite) in a weathering profile form lanthanide- and lanthanide aluminum phosphate minerals rhabdophane $\left[(\mathrm{La}, \mathrm{Ce}) \mathrm{PO}_{4} \cdot \mathrm{H}_{2} \mathrm{O}\right]$ and florencite $\left[(\mathrm{La}, \mathrm{Ce}) \mathrm{Al}_{3}\left(\mathrm{PO}_{4}\right)_{2}(\mathrm{OH})_{6}\right]$ on dissolving apatite $\left[\mathrm{Ca}_{5}\left(\mathrm{PO}_{4}\right)_{3}(\mathrm{OH}, \mathrm{F}, \mathrm{Cl})\right]$ surfaces. In some soils, these are the primary mineral phosphate repositories (Green and others, 2002). In this paper, we investigate the dissolution of cerium phosphate (rhabdophane $\left[\mathrm{CePO}_{4} \cdot \mathrm{H}_{2} \mathrm{O}\right]$ ). We chose the cerium end member for this study as cerium is typically the most abundant lanthanide and generally the only one to undergo redox

*Department of Earth and Planetary Science, University of California, Berkeley, Berkeley, California 94720-4767, USA

**Department of Earth Science, University of Windsor, Windsor, Ontario, N9B 3P4, Canada

${ }^{\dagger}$ Corresponding author: email: javiera@nature.berkeley.edu 
reactions at the Earth's surface. Rhabdophane dissolution is of interest because this mineral represents an important Ce repository in the cerium geochemical cycle.

It has been shown previously that dissolution of phosphate minerals containing Ce may be accompanied by $\mathrm{Ce}^{3+}$ (ag) oxidation and precipitation of nanocrystalline $\mathrm{CeO}_{2(\mathrm{~s})}$ (Gardner and others, 1983; Taunton and others, 2000). A study of the enrichment of Ce in four lateritic soil profiles reported its systematic accumulation (up to $2000 \mathrm{ppm} \mathrm{Ce}$ ) at the top of the saprolite, beneath domains of iron oxides (predominantly goethite) in the laterite, due to $\mathrm{Ce}^{3+}{ }_{\text {(aq) }}$ oxidation to $\mathrm{Ce}^{4+}{ }_{\text {(aq) }}$ (Braun and others, 1990). The oxidation of Ce was reported to occur within cracks, possibly because of access to $\mathrm{O}_{2}$ or decreases in $\mathrm{pH}$ and increase in ionic strength (and decreases in the partial pressure of $\mathrm{CO}_{2}$ ) following goethite precipitation (Braun and others, 1990).

Secondary phosphate mineral dissolution.-Rare-earth orthophosphates such as rhabdophane $\left(\mathrm{CePO}_{4} \cdot \mathrm{H}_{2} \mathrm{O}\right)$ are amongst the most insoluble materials (solubility product $\mathrm{K}_{\mathrm{sp}}=10^{-25}$; Firsching and Brune, 1991). Due to their low solubility, they are used as chemical tracers of natural fluid-rock processes (Ushakov and others, 2001), have been studied widely for lighting applications, long-term storage of nuclear wastes, and are under consideration as host phases for actinides. In the later case, it is assumed that their formation will lead to long term immobilization of structurally incorporated metal ions. However, there is evidence that lanthanide phosphates can be dissolved via biologically-mediated pathways (Ilmer and others, 1995; Taunton and others, 2000).

Microorganisms may secrete low-molecular weight organic compounds that can facilitate mineral dissolution (Leyval and Berthelin, 1989; Johnston and Vestal, 1993; Ilmer and others, 1995). Organic materials secreted by microbes and higher plants impact phosphate release from apatite in soils (Barber and Martin, 1976; Brewster and others, 1976; Nye, 1977, 1979; Kucey and others, 1989). Organic acids can exchange with surface-bound phosphate, resulting in its release of phosphate for plant uptake. For example, Brewster and others (1976) reported phosphate depletion zones around rape roots that were much deeper and wider than predicted from independent measurements of the plants and soils. Polysaccharides may increase the extent of dissolution of apatite by complexing with ions in solution, thereby lowering solution saturation state (Banfield and others, 1999; Welch and others, 1999).

Fluxes of $\mathrm{PO}_{4}^{3-}$ (aq) are susceptible to changes in the redox status of soils and sediments. Phosphate may be sequestered into a variety of iron and manganese minerals such as vivianite $\left[\mathrm{Fe}_{3}\left(\mathrm{PO}_{4}\right)_{2} \cdot 8 \mathrm{H}_{2} \mathrm{O}\right]$, strengite $\left[\mathrm{FePO}_{4} \cdot 2 \mathrm{H}_{2} \mathrm{O}\right]$, amorphous ferric phosphate $\left[\mathrm{FePO}_{4}\right]$, reddingite $\left[\mathrm{Mn}_{3}\left(\mathrm{PO}_{4}\right)_{2} \cdot 3 \mathrm{H}_{2} \mathrm{O}\right]$, hureaulite $\left[\mathrm{Mn}_{5} \mathrm{H}_{2}\left(\mathrm{PO}_{4}\right)_{4} \cdot 4 \mathrm{H}_{2} \mathrm{O}\right]$ and trivalent manganese phosphate $\left[\mathrm{MnPO}_{4} \cdot 1.5 \mathrm{H}_{2} \mathrm{O}\right]$. When redox conditions change, oxidation or reduction of $\mathrm{Fe}$ and $\mathrm{Mn}$ can result in release of $\mathrm{PO}_{4}^{3-}$ (aq) (Moore and Reddy, 1994; Moore and others, 1998; Moore, 1999; Uusitalo and Turtola, 2003).

Taunton and others (2000) noted that when secondary phosphate minerals are the sole source of $\mathrm{PO}_{4}{ }^{3-}{ }_{(\mathrm{aq})}$, microorganisms colonize the mineral surfaces. Based on this, and thermodynamic considerations, they suggested that microorganisms dissolve insoluble secondary phosphates by production of organic ligands that complex lanthanide ions. This, in combination with phosphate uptake, leads to mineral dissolution (Taunton and others, 2000). In this manuscript, we evaluate this hypothesis through study of batch dissolution of $\mathrm{CePO}_{4} \cdot \mathrm{H}_{2} \mathrm{O}$ by ascorbate, citrate, humic acids, oxalate, and commercial EDTA (fig. 1) at $\mathrm{pH} 3,5$, and 8.

Mineral synthesis and characterization.-Cerium phosphate was synthesized from fast mixing of $0.5 \mathrm{M}$ phosphoric acid and cerium chloride solutions at $20{ }^{\circ} \mathrm{C}$, as 


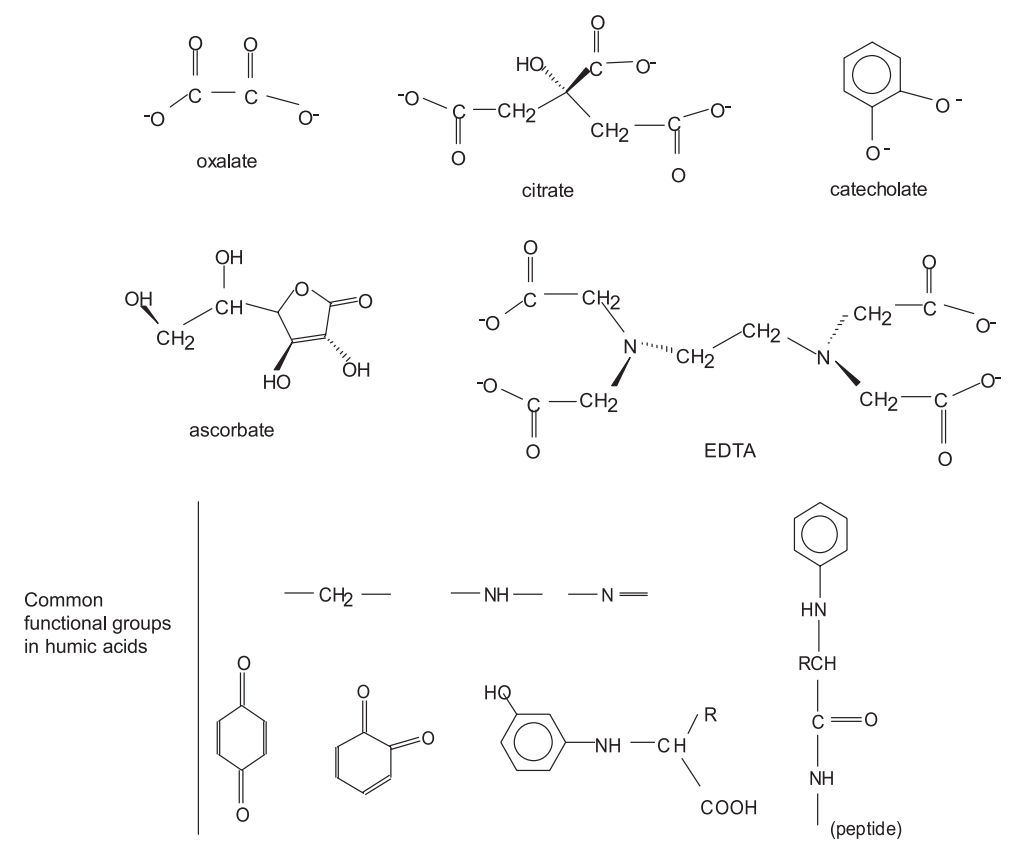

Fig. 1. Molecular structure of selected biogenic organic ligands.

described elsewhere (Hikichi and others, 1978). Powder X-ray diffracton (Co K $\alpha$ radiation) analysis confirmed that the synthesized solid was rhabdophane, with characteristic peaks assigned to the 200, 101, 102, 100, 211, 212, 110, and 203 reflections (fig. 2). Cerium oxide $\left(\mathrm{CeO}_{2}\right)$ was purchased from Aldrich and used as received. Specific surface areas for $\mathrm{CePO}_{4} \cdot \mathrm{H}_{2} \mathrm{O}$ and $\mathrm{CeO}_{2}$ samples were $66 \pm 1$ and $19.7 \pm 1 \mathrm{~m}^{2} \mathrm{~g}^{-1}$, as determined by the static BET method.

Attenuated total reflection-Fourier transform infrared (ATR-FTIR) spectra of $\mathrm{CePO}_{4} \cdot \mathrm{H}_{2} \mathrm{O}$ and $\mathrm{CeO}_{2}$ samples were collected using a Nexus 470 spectrometer (Nicolet, Madison, WI). The sample cell was purged with nitrogen gas for one hour before data collection. Two to five thousand scans were collected for each pellet $(\leq$ $1 \% \mathrm{w} / \mathrm{w} \mathrm{KBr}$ ) over the range 400 to $4000 \mathrm{~cm}^{-1}$, with a resolution of 2 and $4 \mathrm{~cm}^{-1}$ (fig. 3).

Organic carbon contents of the mineral samples were determined by thermogravimetry. Particle morphology and aggregate structure of $\mathrm{CePO}_{4} \cdot \mathrm{H}_{2} \mathrm{O}$ samples were determined by high-resolution scanning electron microscopy.

Mineral dissolution.-Dissolution of $\mathrm{CePO}_{4} \cdot \mathrm{H}_{2} \mathrm{O}$ was investigated via batch experiments with $1 \mathrm{mM}$ ligand concentration and $\mathrm{pH}$ adjusted to 3.0 through 8.0, solids concentration of $1 \mathrm{~g} \mathrm{~L}^{-1}$, and constant stirring for a period of 10 to 15 days. Organic ligands selected include ascorbate, citrate, humic acids, oxalate, and EDTA (fig. 1). Control experiments were conducted to study mineral dissolution at $\mathrm{pH} 3,5$, and 8 in the absence of organic ligands. In all cases, triplicate experiments were conducted. After equilibration, the suspensions were centrifuged and the supernatant solutions filtered using $0.25-\mu \mathrm{m}$ Whatman syringe filters before $\mathrm{Ce}_{(\mathrm{aq})}$ and $\mathrm{PO}_{4}{ }^{3-}{ }_{(\mathrm{aq})}$ determination. Analyses of $\mathrm{Ce}_{(\mathrm{aq})}$ and $\mathrm{PO}_{4}{ }^{3-}{ }_{(\mathrm{aq})}$ were conducted using inductively coupled plasma atomic emission spectrometer (ICP-AES, Jarrel Ash, MO) with emission lines at 418.6, and $178.7 \mathrm{~nm}$, respectively. Analyses were corroborated using an inductively-coupled plasma mass spectrometer (ThermoEle- 


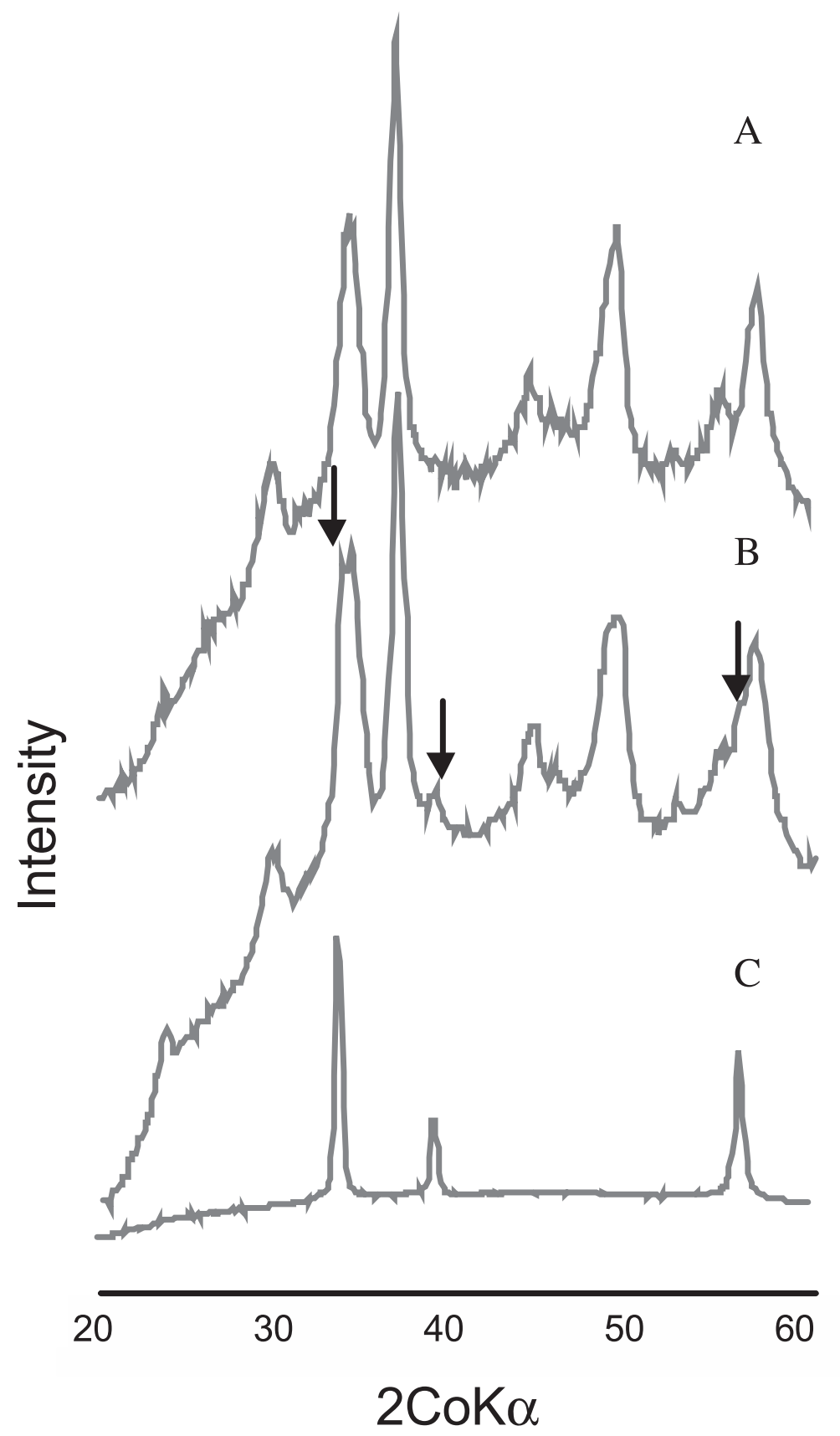

Fig. 2. XRD diffraction pattern of (A) $\mathrm{CePO}_{4} \cdot \mathrm{H}_{2} \mathrm{O}$, (B) $\mathrm{CePO}_{4} \cdot \mathrm{H}_{2} \mathrm{O}$ reacted in the presence of humic acids, and (C) $\mathrm{CeO}_{2}$ reference spectra.

mental X7, Mississauga, Canada) with a collision cell. Mass bias drift was corrected using a three element (Be, In, Tl) internal standard. In all cases, duplicate analyses were conducted. 


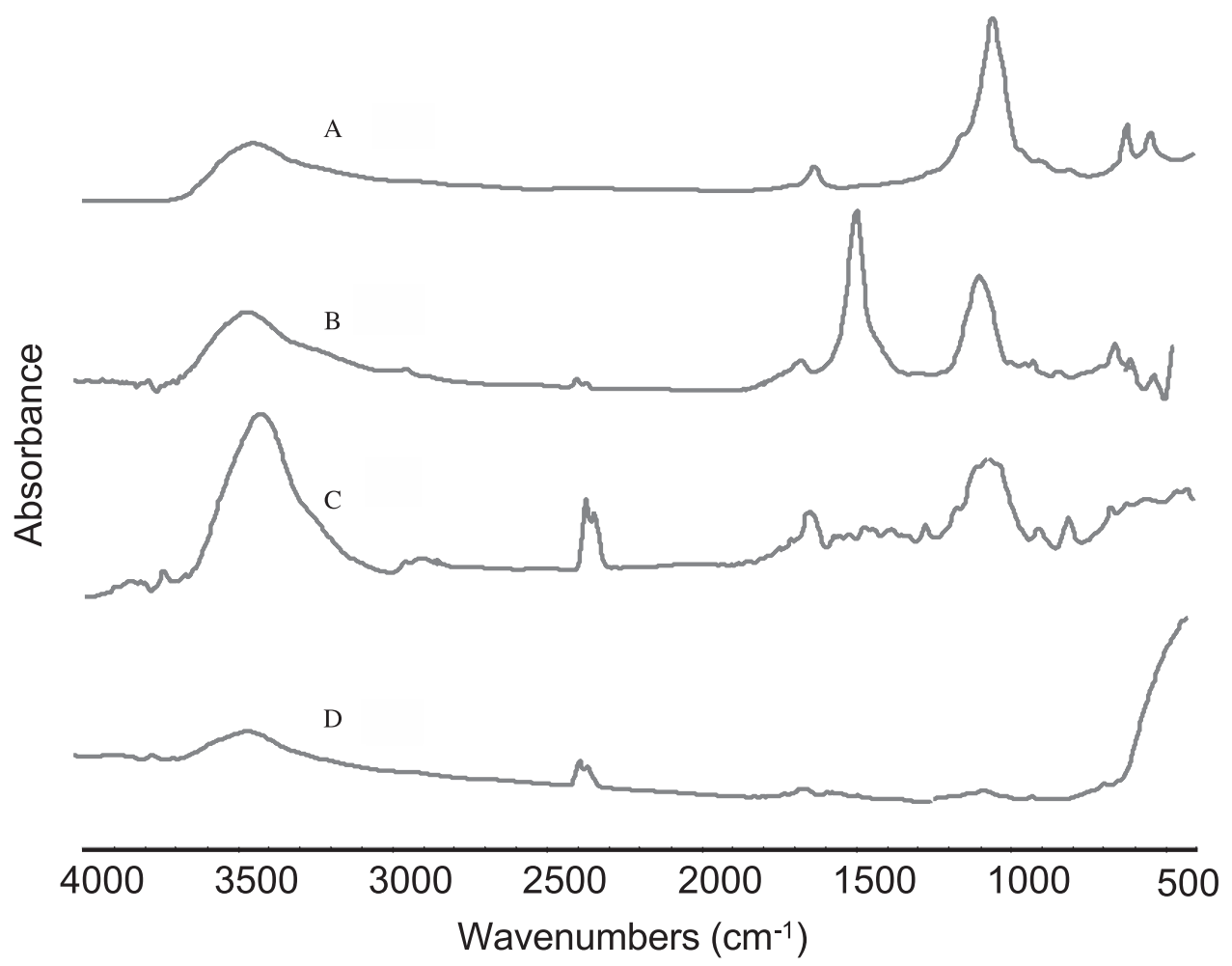

Fig. 3. FTIR spectra (Absorbance) of $\mathrm{CePO}_{4} \cdot \mathrm{H}_{2} \mathrm{O}$ reacted with catechol confirms the presence of $\mathrm{CeO}_{2}$. Spectra for (A) $\mathrm{CePO}_{4} \cdot \mathrm{H}_{2} \mathrm{O},(\mathrm{B}) \mathrm{CePO}_{4} \cdot \mathrm{H}_{2} \mathrm{O}$ reacted with humic acids, (C) $\mathrm{CePO}_{4} \cdot \mathrm{H}_{2} \mathrm{O}$ reacted with catecholate, and (D) $\mathrm{CeO}_{2}$ reference spectra.

Speciation calculations were performed with J-Chess 2.0 with stability constants from Martell and Smith (1972) added to the standard JChess thermodynamic database (van der Lee, 1998).

\section{RESULTS AND DISCUSSION}

\section{Solid Characterization}

X-ray diffraction patterns of synthetic powders of $\mathrm{CePO}_{4} \cdot \mathrm{H}_{2} \mathrm{O}$ dissolved in humic acid, ascorbate and citrate solutions show characteristic peaks that can be assigned to (111), (220), and (311) $\mathrm{CeO}_{2}$ (fig. 2). Infrared spectra of reacted $\mathrm{CePO}_{4} \cdot \mathrm{H}_{2} \mathrm{O}$ samples also confirm the presence of characteristic $\mathrm{CeO}_{2}$ peaks at $2360 \mathrm{~cm}^{-1}$ (fig. 3) (Pouchert, 1997). Qualitatively, as revealed by IR band intensities (fig. 3), the extent of $\mathrm{CeO}_{2}$ formation depends in part on the molecular structure of the organic ligand.

Previously, we report that the reaction between aqueous $\mathrm{Ce}^{3+}{ }_{(\mathrm{aq})}$ and $\mathrm{O}_{2}$ at room temperature is very slow, but can be accelerated if catechol is added (Cervini-Silva and Banfield, 2003). Complexation of humic acid, ascorbate, or citrate with $\mathrm{Ce}^{3+}{ }_{(\mathrm{aq})}$ ions may have facilitated cerium oxidation, as previously described for $\mathrm{Mn}^{3+}$ complexes (Morrison and others, 1977; Magers and others, 1978; Pierpont and Buchanan, 1981; Sheriff, 1992; Gelasco and others, 1998). Complex formation, results in a dramatic decrease in redox potential of $\mathrm{Ce}^{3+}{ }_{(\text {aq) }}$, as indicated by the potential values: $\mathrm{E}_{\mathrm{Ce}(\mathrm{IV}) / \mathrm{Ce}(\mathrm{III})}=+1.61 \mathrm{~V}$,

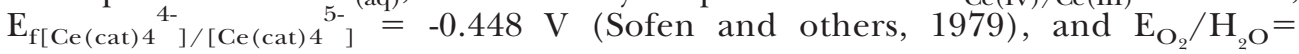




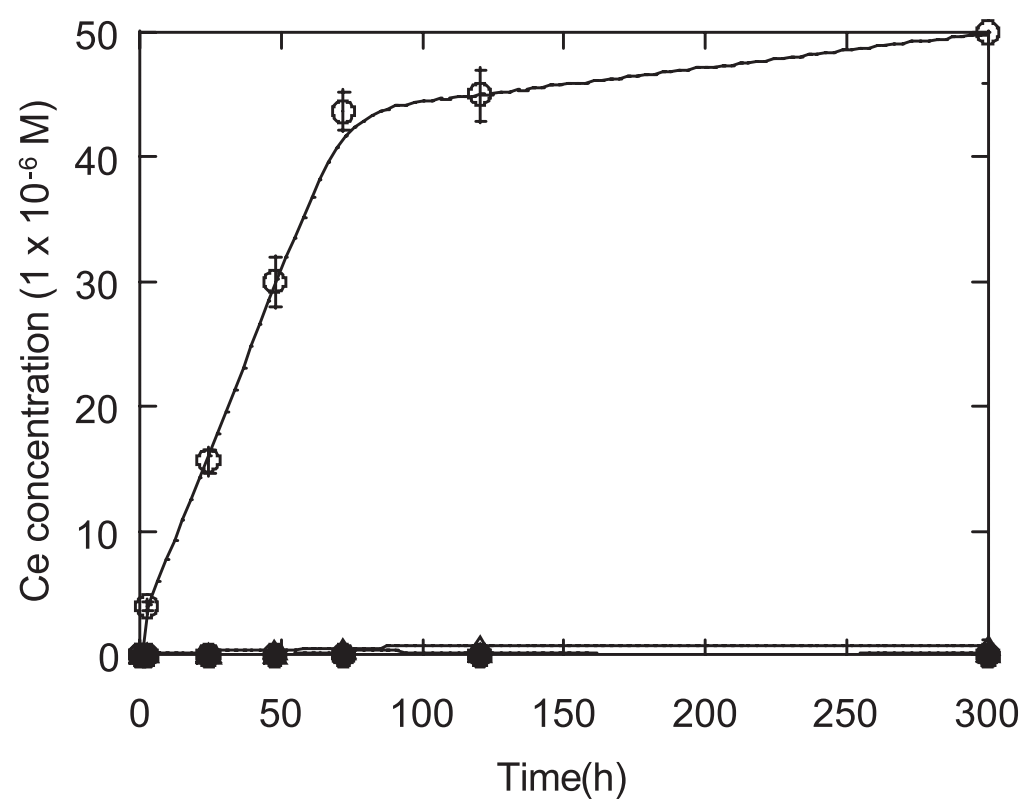

Fig. 4. Simulation of Ce in solution over time after the reaction between $\mathrm{CePO}_{4} \cdot \mathrm{H}_{2} \mathrm{O}$ and (A) oxalate (solid triangles), (B) citrate (solid dots), (C) ascorbate (solid squares), (D) humic acids (open triangles), and (E) EDTA (open dots) at pH 5. In the absence of organic ligands, the average values for the release of Ce after 900 h-reaction time did not exceed $1.2 \pm 0.3 \times 10^{-8} \mathrm{M}$. Error bars indicate twice the standard deviation of triplicate sample measurements. Lines are to aid the eye and do not indicate a model fit.

$+1.229 \mathrm{~V}$ (Stumm and Morgan, 1996). Thus, the complexed $\mathrm{Ce}^{3+}$ can be readily oxidized by $\mathrm{O}_{2}$.

Mineral dissolution. - In the absence of organic ligands, the average values for the release of $\mathrm{Ce}_{(\mathrm{aq})}$ or $\mathrm{PO}_{4}^{3-}$ (aq) after 900 h-reaction time were comparable and did not exceed $1.2 \pm 0.3 \times 10^{-6} \mathrm{M} \mathrm{PO}_{4}{ }^{3-}(\mathrm{aq})$ or $\mathrm{Ce}_{(\mathrm{aq})}$. Figures 4 through 9 illustrate the dissolution behavior of $\mathrm{CePO}_{4} \cdot \mathrm{H}_{2} \mathrm{O}$ in the presence of oxalate, citrate, ascorbate, humic acids, and EDTA at $3<\mathrm{pH}<8$. Figures 4, 5, and 6 illustrate detectable $\left[\mathrm{Ce}_{(\mathrm{aq})}\right]$ and figures 7, 8, and 9 illustrate detectable $\left[\mathrm{PO}_{4}{ }^{3-}{ }_{(\mathrm{aq})}\right]$ in solution at $\mathrm{pH} 5,3$, and 8, respectively. Solubility calculations of $\mathrm{CePO}_{4} \cdot \mathrm{H}_{2} \mathrm{O}$ in the presence of organic ligands are illustrated in figure 10 with complimentary speciation calculations in table 1.

Release of Ce.-Both the molecular structure of organic ligands and the solution $\mathrm{pH}$ influence the extent of Ce release from $\mathrm{CePO}_{4} \cdot \mathrm{H}_{2} \mathrm{O}$.

EDTA. The accumulation of $\mathrm{Ce}_{(\mathrm{aq})}$ after the reaction between $\mathrm{CePO}_{4} \cdot \mathrm{H}_{2} \mathrm{O}$ and

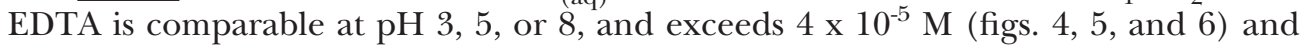
approaches congruent release with phosphate (fig. 10). With the exception of oxalate at $\mathrm{pH} 3$ (fig. 5), the effectiveness of EDTA surpasses that of biogenic ligands in releasing $\mathrm{Ce}_{(\mathrm{aq})}$ to solution. Fast- followed by slow-dissolution kinetics may be a result of early removal of high-energy sites (for example kinks, steps, et cetera) at the solid surface (Stumm and others, 1987; Sposito, 1994; Lasaga, 1994) or due to a more rapid dissolution of a subset of smaller particles within the sample (Langmuir, 1969; Trolard and Tardy, 1987).

Speciation calculations for EDTA with initial concentration $1 \mathrm{mM}$ and $\mathrm{pH} 3$ (data not shown) indicate that the concentrations for $\mathrm{H}_{2}-\mathrm{EDTA}^{2-}, \mathrm{H}_{3}-\mathrm{EDTA}^{1-}, \mathrm{EDTA}_{(\mathrm{aq})}$, H-EDTA ${ }^{3-}$, and EDTA $^{4-}$ approximate $8.2 \times 10^{-4}, 1.4 \times 10^{-4}, 2.1 \times 10^{-5}, 5.1 \times 10^{-7}, 7.1 \times 10^{-15} \mathrm{~mol}$ 


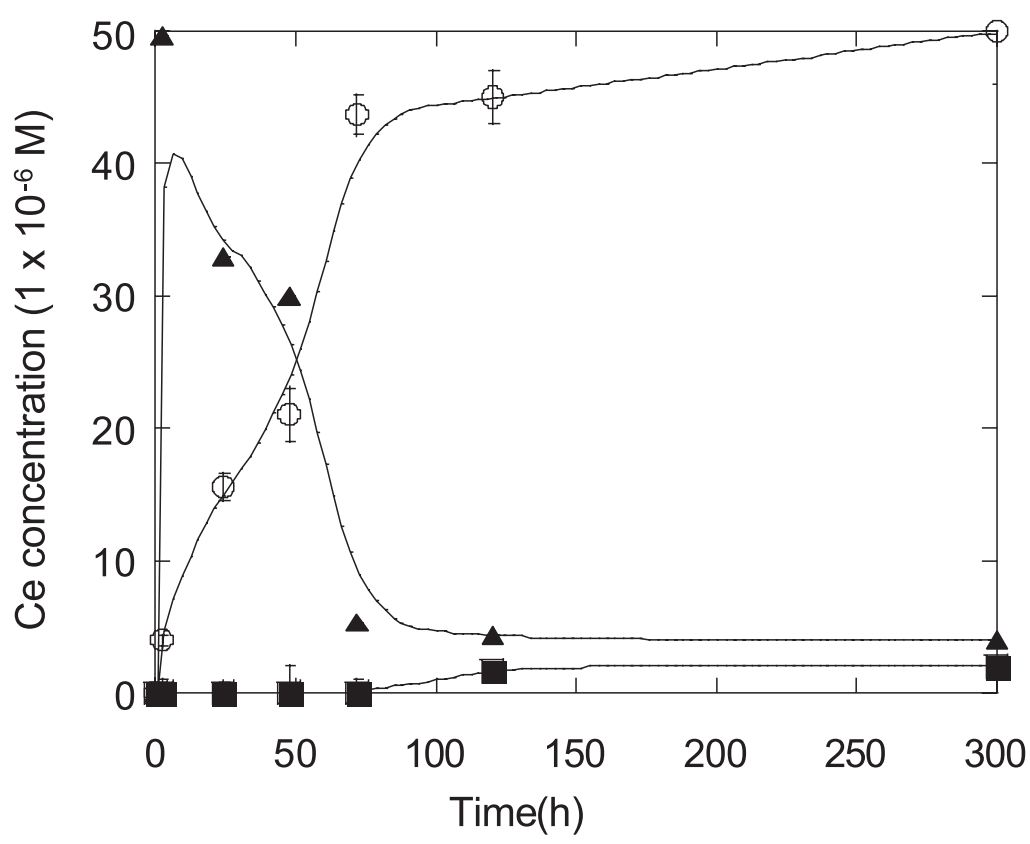

Fig. 5. Accumulation of Ce in solution over time after the reaction between $\mathrm{CePO}_{4} \cdot \mathrm{H}_{2} \mathrm{O}$ and (A) oxalate (solid triangles), (B) citrate (solid dots), (C) ascorbate (solid squares), (D) humic acids (open triangles), and (E) EDTA (open dots) at $\mathrm{pH} 3$. In the absence of organic ligands, the average values for the release of Ce after 900 h-reaction time did not exceed $1.2 \pm 0.3 \times 10^{-6} \mathrm{M}$. Error bars indicate twice the standard deviation of triplicate sample measurements. Lines are to aid the eye and do not indicate a model fit.

$\mathrm{L}^{-1}$, respectively. Thus, EDTA (predominantly as $\mathrm{H}_{2}-\mathrm{EDTA}^{2-}$ ) is thought to promote the release of $\mathrm{Ce}_{(\mathrm{aq})}\left(<5 \times 10^{-5} \mathrm{M}\right)$ by means of complexation. Intriguingly the release of $\mathrm{Ce}_{(\mathrm{aq})}$ is an order of magnitude higher than predicted (fig. 10) from solubility calculations in the presence of EDTA. This may represent an incomplete dataset with regard to published Ce-EDTA stability complexes. No inhibition of dissolution due to EDTA surface complexation (Bondietti and others, 1993; Biber and others, 1994) was apparent. Data illustrated in figures 4, 5, and 6 show maximum values for $\mathrm{Ce}_{(\mathrm{aq})}$ release that do not surpass $5 \times 10^{-5} \mathrm{M}$. As predicted from

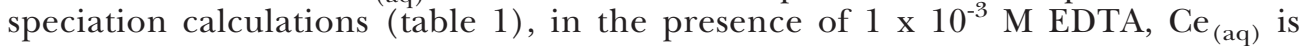
predominantly complexed by EDTA.

Oxalate. Oxalate promotes the dissolution of $\mathrm{CePO}_{4} \cdot \mathrm{H}_{2} \mathrm{O}$. In part, this may be explained by the model that Welch and Ullman (1992) developed to account for oxalate-promoted mineral dissolution of feldspar. The authors proposed that the protonated ligand forms a complex with a surface aluminum group, and loses $\mathrm{a}^{+}$ that adsorbs to a neighboring site. Similar findings of a strong dependency of dissolution on proton and ligand attack of the mineral surface are reported for a series of plagioclase feldspars (Welch and Ullman, 1996).

At $\mathrm{pH}$ 3, a fast release of $\mathrm{Ce}_{(\mathrm{aq})}$ within the first $2 \mathrm{hrs}$ of reaction time is followed by a sharp decrease in $\mathrm{Ce}_{(\mathrm{aq})}$ concentration (fig. 5). Concentrations of $\mathrm{Ce}_{(\mathrm{aq})}$ at 2 and $100 \mathrm{~h}$ reaction time approach 40 and $5 \times 10^{-6} \mathrm{M}$, respectively. The concentration of $\mathrm{Ce}_{(\mathrm{aq})}$ in solution with time is consistent with mineral dissolution followed by precipitation. Early accumulation of $\mathrm{Ce}_{(\mathrm{aq})}$ in the presence of oxalate at $\mathrm{pH} 3$ may involve the formation of polydentate complexes $\mathrm{Ce}(\mathrm{ox})_{2}{ }^{-}$over $\mathrm{Ce}(\mathrm{ox})^{+}$(table 1) (Sillen, 1971). As 


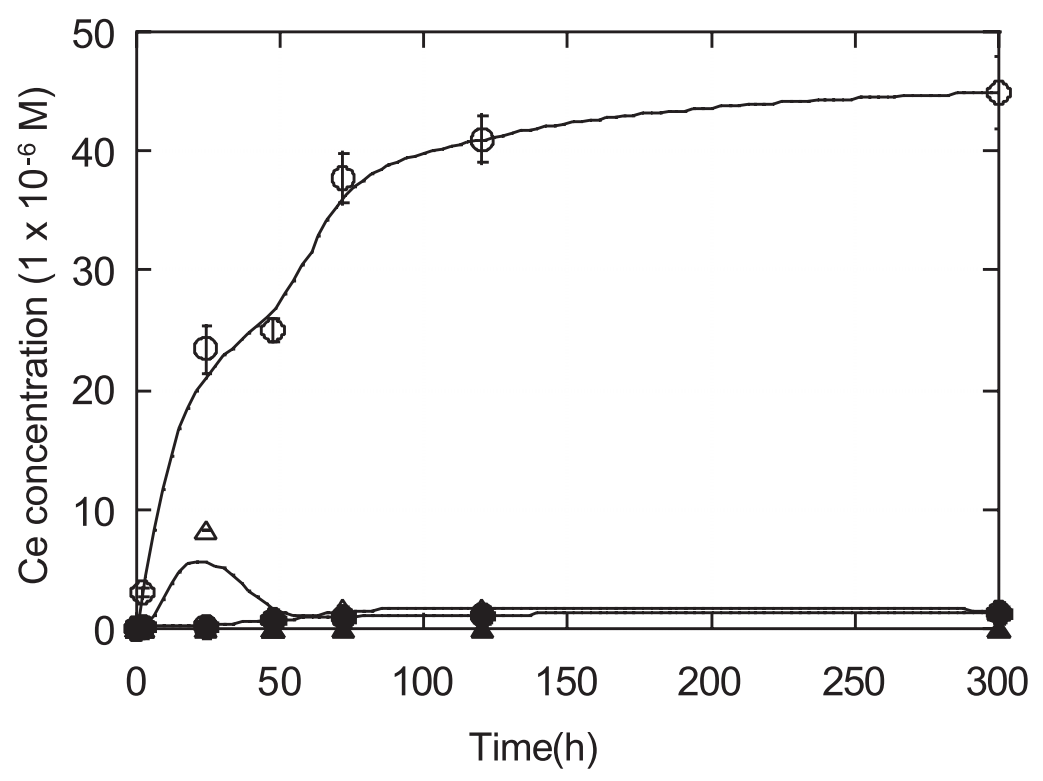

Fig. 6. Accumulation of $\mathrm{Ce}$ in solution over time after the reaction between $\mathrm{CePO}_{4} \cdot \mathrm{H}_{2} \mathrm{O}$ and (A) oxalate (solid triangles), (B) citrate (solid dots), (C) ascorbate (solid squares), (D) humic acids (open triangles), and (E) EDTA (open dots) at pH 8. In the absence of organic ligands, the average values for the release of Ce after 900 h-reaction time did not exceed $1.2 \pm 0.3 \times 10^{-6} \mathrm{M}$. Error bars indicate twice the standard deviation of triplicate sample measurements. Lines are to aid the eye and do not indicate a model fit.

the cerium concentration in solution increases, $\mathrm{Ce}^{3+}$-oxalate clusters $(\mathrm{Xu}$ and others, 2002) may precipitate, forming highly insoluble $\mathrm{Ce}_{2}\left(\mathrm{C}_{2} \mathrm{O}_{4}\right)_{3(\mathrm{~s})}$ (Hyun and others, 2002). The sharp depletion of Ce in solution after 2-hrs of reaction time (fig. 5) may be the consequence of a high activation barrier for nucleation of the solid. When compared to calculated solubilities the total aqueous Ce concentrations after $300 \mathrm{~h}$ are comparable to the experimentally derived values and follow the decrease in release with increasing $\mathrm{pH}$ (fig. 10) (excluding $\mathrm{pH} 5$ which was below detection). This same figure illustrates the departure of the Ce and $\mathrm{P}$ data with increasing $\mathrm{pH}$ values and supports the hypothesis of incongruent dissolution with precipitation of a discrete Ce phase that does not contain phosphorus.

Ascorbate, humic acids, and citrate. As noted above, reaction between $\mathrm{CePO}_{4} \cdot \mathrm{H}_{2} \mathrm{O}$ and these organic compounds lead to precipitation of $\mathrm{CeO}_{2}$ (fig. 2). In the case of ascorbate, we observed formation of a yellow precipitate, a typical ascorbate oxidation product (a diprotonated acid, $\mathrm{H}_{2} \mathrm{~A}$; Khan and Martell, 1967; Buettner and others, 1978; Martell, 1982; Buettner, 1988). This observation strongly suggests electron transfer between a cerium species, presumably $\mathrm{Ce}^{4+}$ in $\mathrm{CeO}_{2}$, and ascorbate. At pH 5 , the ascorbate anion $\left(\mathrm{AH}^{-}\right)$is the predominant form of ascorbate (Bendich and others, 1986). Upon oxidation, ascorbate forms stable radical intermediates due to resonanceinduced charge delocalization. For example, $\mathrm{AH}^{-}$can participate in electron transfer to form ascorbyl radical $\mathrm{A}^{-\bullet}$. In solution, $\mathrm{A}^{\bullet}$ may participate in disproportionation reactions or react with radicals intermediates leading to the formation of oxidative polymers (Buettner and others, 1978; Buettner, 1988). Hydrogen bonding associations between ascorbate molecules may also favor ascorbate oxidative polymerization (Buettner and others, 1978; Buettner, 1988). There is strong support of this conceptual model from the clear incongruent dissolution of our starting material and the solid phase characterization of the secondary Ce phase. 


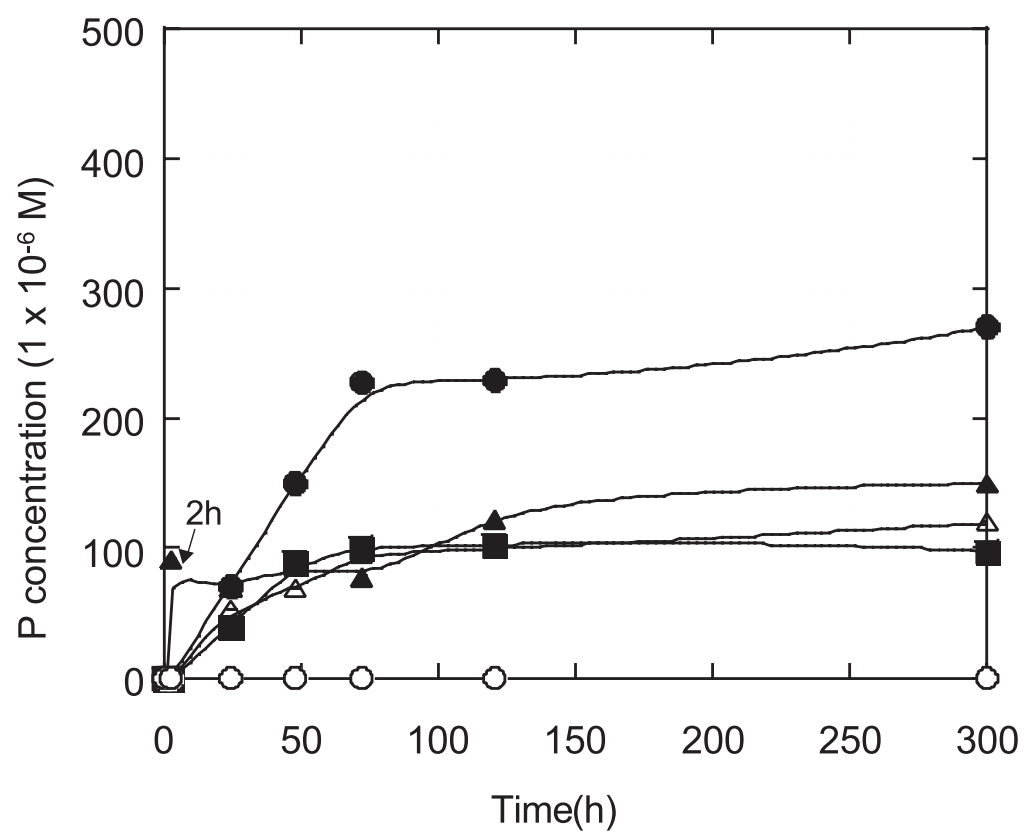

Fig. 7. Accumulation of $\mathrm{PO}_{4}{ }^{3-}{ }_{(\mathrm{aq})}$ in solution over time after the reaction between $\mathrm{CePO}_{4} \cdot \mathrm{H}_{2} \mathrm{O}$ and (A) oxalate (solid triangles), (B) citrate (solid dots), (C) ascorbate (solid squares), (D) humic acids (open triangles), and (e) EDTA (open dots) at $\mathrm{pH} 5$. In the absence of organic ligands, the average values for the release of $\mathrm{PO}_{4}^{3-}(\mathrm{aq})$ after $900 \mathrm{~h}$-reaction time did not exceed $1.2 \pm 0.3 \times 10^{-6} \mathrm{M}$. Error bars indicate twice the standard deviation of triplicate sample measurements. Lines are to aid the eye and do not indicate a model fit.

The oxidative polymerization of ascorbate parallels a report of catechol oxidative polymerization after reaction with $\mathrm{CeO}_{2}$ under oxic conditions at $\mathrm{pH} 5$ (Cervini-Silva and Banfield, 2003). Like ascorbate, catechol forms resonance-stabilized radical intermediates. The fact that both ascorbate and catechol undergo facile oxidation is explained by their susceptibility to transfer charge to an electron acceptor, as revealed by their standard reduction potential values (Larson, 1998).

Although speciation calculations (table 1) to predict the formation of stable complexes between $\mathrm{Ce}^{3+}$ and citrate, no accumulation of cerium was observed in solution at $\mathrm{pH} 3$ and 5 (figs. 4 and 5). Complexation models predict essentially no release of cerium in the presence of ascorbate (stability constant data was not available for the humic material used in this study). This may indicate that most cerium released by dissolution has been oxidized to $\mathrm{Ce}^{4+}$. Alternatively, $\mathrm{Ce}^{3+}$ complexes may be bound to the surface, possibly via charge transfer between $\pi$-electron density of the carboxylate groups (ascorbate) or the benzene ring (catechol) and the $\mathrm{CePO}_{4} \cdot \mathrm{H}_{2} \mathrm{O}$ surface. For the case of citrate, our results show little accumulation of Ce following $\mathrm{CePO}_{4} \cdot \mathrm{H}_{2} \mathrm{O}$ dissolution in all experiments, implying either strong cerium oxidation or specific binding between the Ce-citrate complex and the mineral surface at all $\mathrm{pH}$ values (Bondietti and others, 1993; Biber and others, 1994). The latter hypothesis is supported by the release of $\mathrm{Ce}\left(2 \times 10^{-6} \mathrm{M}\right.$ at $\left.300 \mathrm{~h}\right)$ at $\mathrm{pH} 8$ which is higher than calculated ligand promoted dissolution equilibrium concentration of Ce of $1 \times 10^{-8} \mathrm{M}$. Furthermore the surface charge of most phosphate mineral phases is predominantly negative at this $\mathrm{pH}$ value leading to net repulsion of citrate from the surface of the mineral (for example, Stumm and Morgan, 1996) and likely enhancing aqueous complexation. 


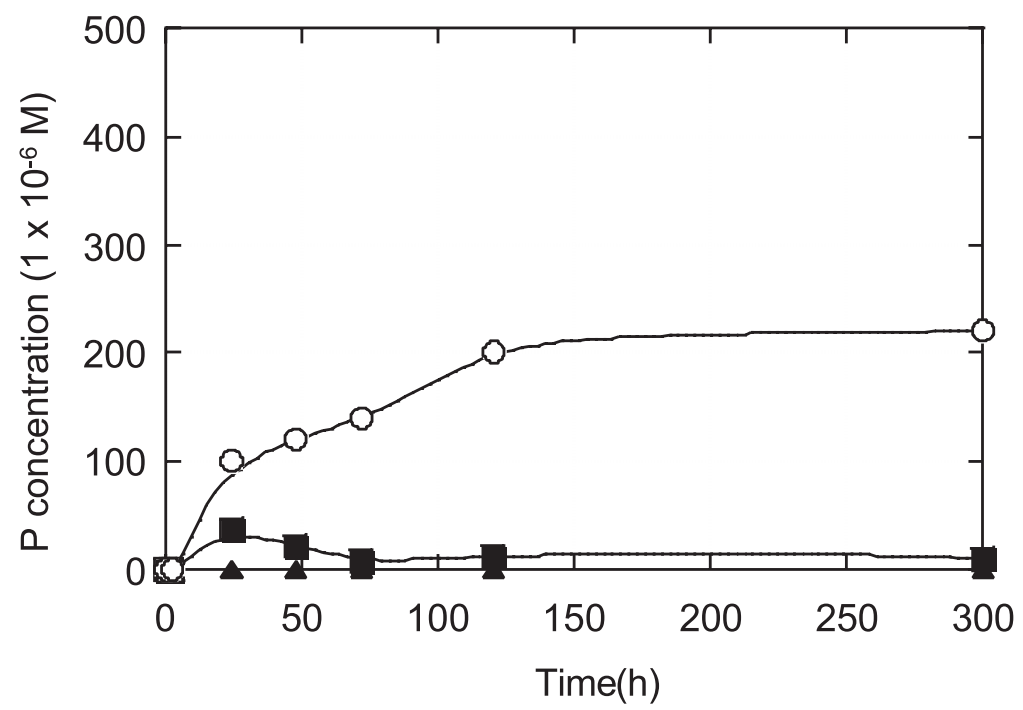

Fig. 8. Accumulation of $\mathrm{PO}_{4}{ }^{3-}(\mathrm{aq})$ in solution over time after the reaction between $\mathrm{CePO}_{4} \cdot \mathrm{H}_{2} \mathrm{O}$ and (A) oxalate (solid triangles), (B) ascorbate (solid squares), and (C) EDTA (open dots) at pH 3. In the absence of organic ligands, the average values for the release of $\mathrm{PO}_{4}{ }^{3-}$ (aq) after $900 \mathrm{~h}$-reaction time did not exceed $1.2 \pm$ $0.3 \times 10^{-6} \mathrm{M}$. Error bars indicate twice the standard deviation of triplicate sample measurements. Lines are to aid the eye and do not indicate a model fit.

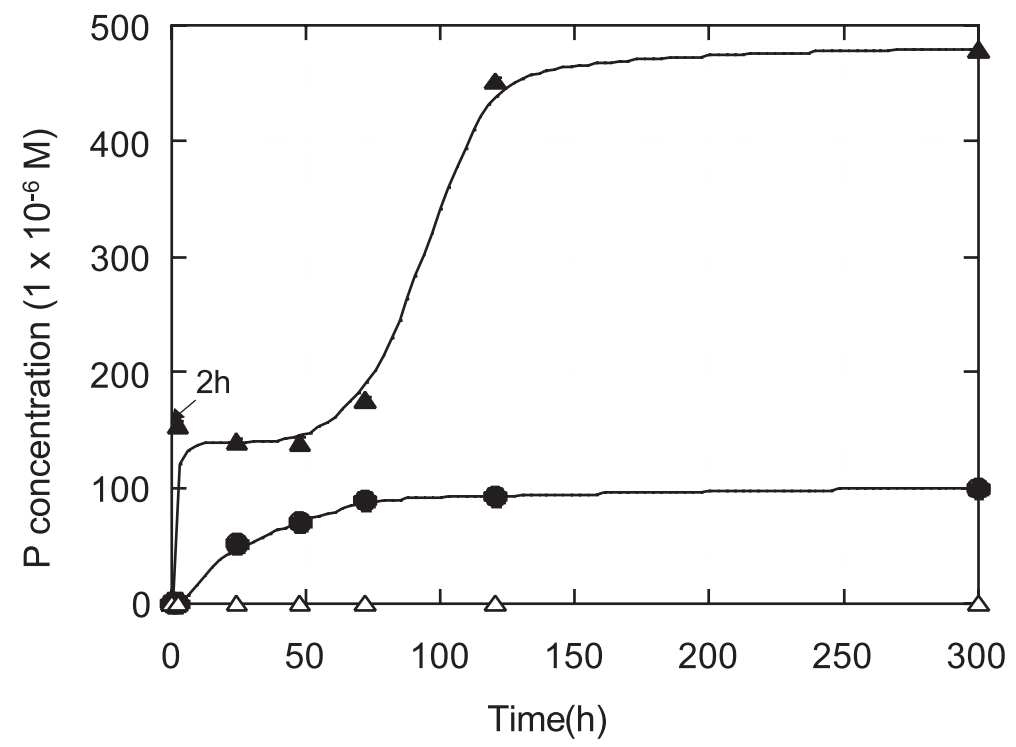

Fig. 9. Accumulation of $\mathrm{PO}_{4}{ }^{3-}$ (aq) in solution over time after the reaction between $\mathrm{CePO}_{4} \cdot \mathrm{H}_{2} \mathrm{O}$ and (A) oxalate (solid triangles), (B) citrate (solid dots), (C) ascorbate (solid squares), (D) humic acids (open triangles), and (E) EDTA (open dots) at $\mathrm{pH}$ 8. In the absence of organic ligands, the average values for the release of $\mathrm{PO}_{4}{ }^{3-}$ (aq) after 900 h-reaction time did not exceed $1.2 \pm 0.3 \times 10^{-6} \mathrm{M}$. Error bars indicate twice the standard deviation of triplicate sample measurements. Lines are to aid the eye and do not indicate a model fit. 

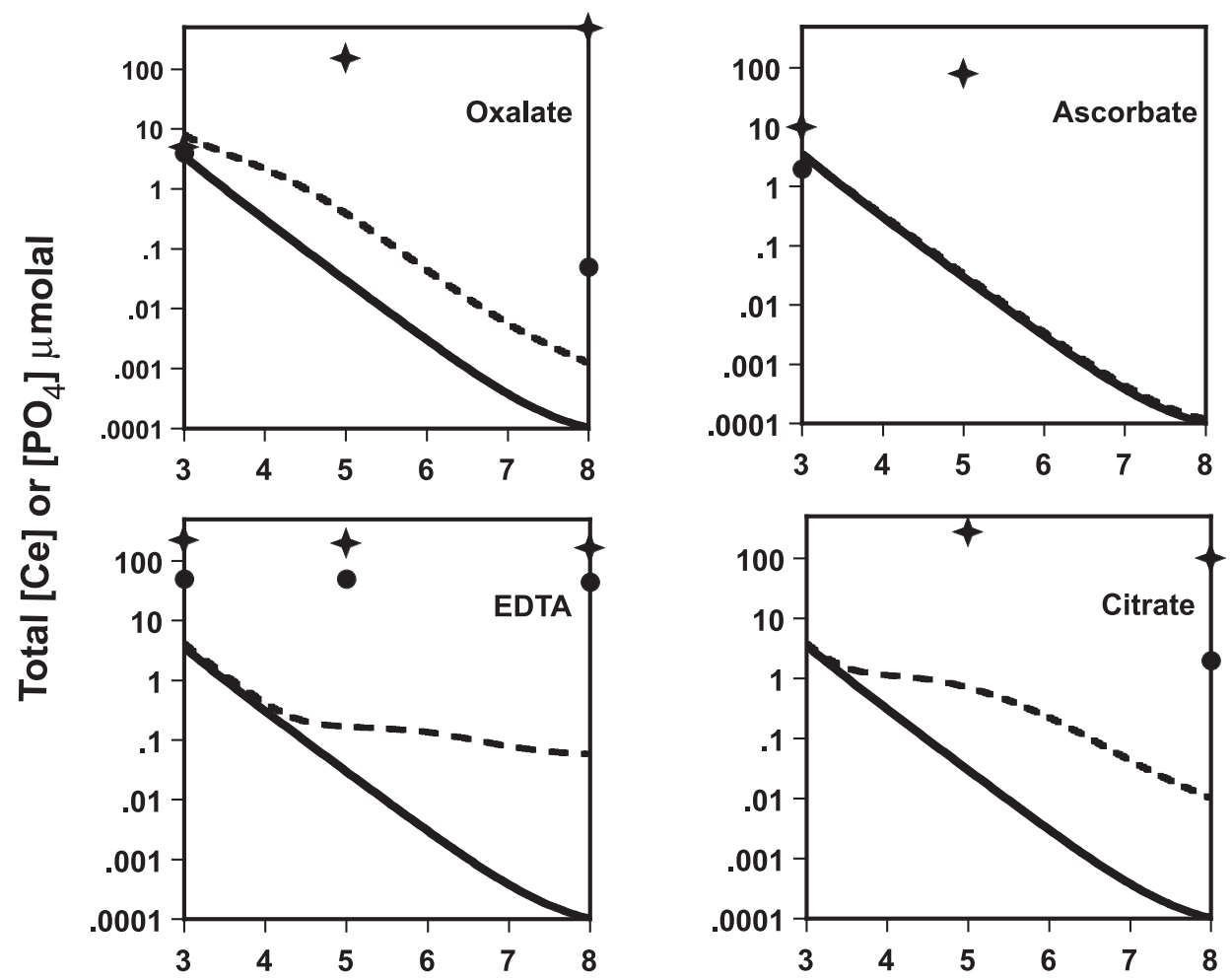

$\mathrm{pH}$

Fig. 10. Solubility calculations for $\mathrm{CePO}_{4} \cdot \mathrm{H}_{2} \mathrm{O}$ in the presence of oxalate, citrate, ascorbate, and EDTA. The initial concentration of $\mathrm{CePO}_{4} \cdot \mathrm{H}_{2} \mathrm{O}$ was set $1 \mathrm{~g} / \mathrm{L}$, the ligands at 1 mmolal, and pH was varied from 3 to 8 . Solid and dotted lines correspond to Ce and $\mathrm{P}$ release in the absence and presence of ligands respectively. Stars and dots represent the experimental release of total phosphate and total cerium respectively after $300 \mathrm{~h}$ reaction time.

The effectiveness of humic acids in releasing Ce from the mineral surface was negligible relative to that of small organic ligands (figs. 4, 5, and 6). Ochs (1996) compared to the rates of dissolution of $\gamma-\mathrm{Al}_{2} \mathrm{O}_{3}$ by non-humified (root exudates and simple ligands) soil organic compounds and humic substances $\left(3 \mathrm{mg} \mathrm{L}^{-1}\right)$ at $\mathrm{pH} 3$ to $\mathrm{pH}$ 4.5. The average particle diameter and specific BET surface area of $\gamma-\mathrm{Al}_{2} \mathrm{O}_{3}$ samples used in that study were $20 \mathrm{~nm}$ and $100 \pm 15 \mathrm{~m}^{2} \mathrm{~g}^{-1}$. Results reported therein show that unlike salycilate, oxalate, or mycorrhyzal exudates, the enhancement in mineral dissolution by humic acids relative to small organic acids is modest. In that study it was proposed that humified compounds prevent dissolution through blocking of surface sites by adsorbing molecules, thus precluding detachment of the metal centers. Similarly, earlier work reports that weathering rates in pine rhizospheric soil subjected to small organic acid exudates may be significantly higher than in the bulk soil, where humic compounds predominate (Leyval and Berthelin, 1991). The role attributed to humic acids in mineral weathering has evolved considerably (Tan, 1980; McKeague and others, 1986; Berner, 1992; Blaser, 1994; Ochs, 1996, and references therein). The present work supports the emerging view that small organic compounds play a more important role of humic compounds in mineral dissolution. 


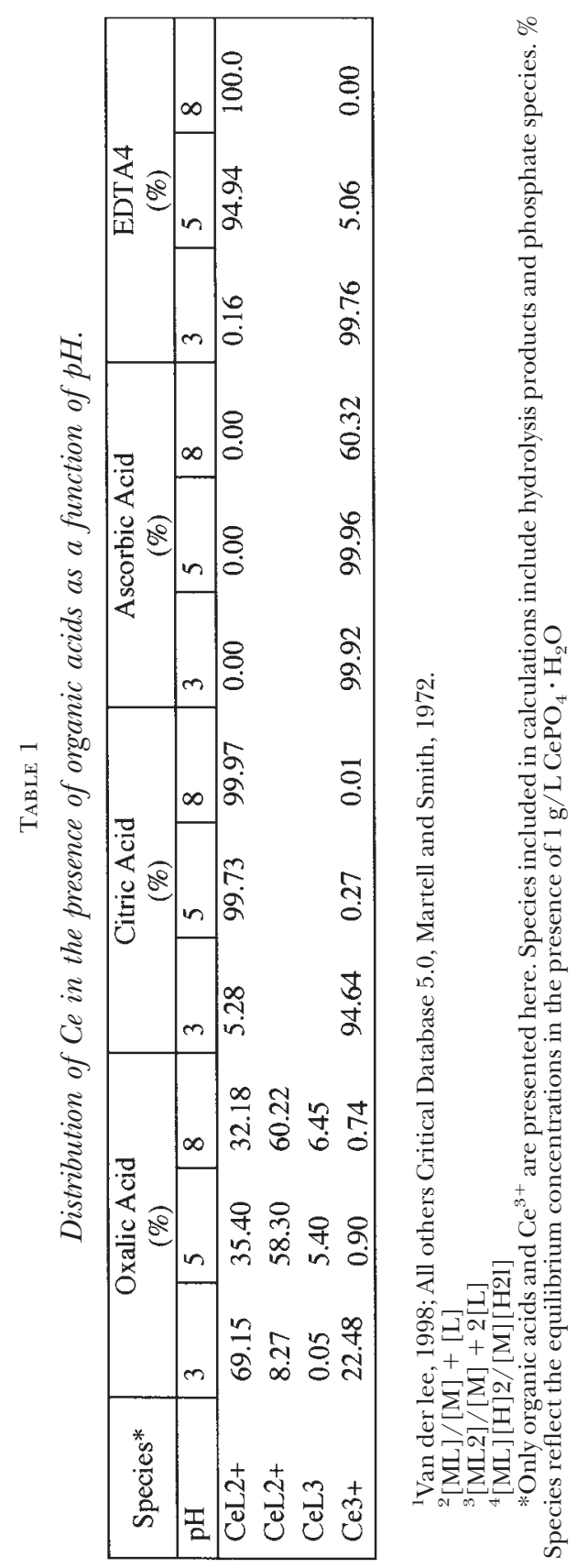


Release of phosphorous. - The molecular structure of organic ligands and the solution $\mathrm{pH}$ strongly influence the release of $\mathrm{PO}_{4}{ }^{3-}$ (aq) (figs. 7, 8, and 9). With the exception of oxalate at $\mathrm{pH} 5$, the ligand that leads to the highest solution phosphate concentration is also the one that causes the mineral to dissolve fastest. Figure 10 depicts the predicted release of phosphate based on the $\mathrm{K}_{\mathrm{sp}}$ of $\mathrm{CePO}_{4} \cdot \mathrm{H}_{2} \mathrm{O}$ and the stability constants of the ligand-Ce complexes. The model calculations predict the following order and extent of phosphate release assuming congruent dissolution of the mineral phase: $p H 3$ oxalate $\left(7.90 \times 10^{-6} \mathrm{M}\right)$, EDTA $\left(4.05 \times 10^{-6} \mathrm{M}\right)$, oxalate $(3.74 \mathrm{x}$ $\left.10^{-6} \mathrm{M}\right)$, and ascorbate $\left(3.57 \times 10^{-6} \mathrm{M}\right) ;$ pH 5 citrate $\left(7.0 \times 10^{-7} \mathrm{M}\right)$, oxalate $\left(3.9 \times 10^{-7}\right.$ $\mathrm{M})$, EDTA $\left(1.7 \times 10^{-7} \mathrm{M}\right)$, and ascorbate $\left(3 \times 10^{-8} \mathrm{M}\right)$; $p H 8$ EDTA $\left(6 \times 10^{-8} \mathrm{M}\right)$, citrate $(1$ $\left.\times 10^{-8} \mathrm{M}\right)$, oxalate $\left(1 \times 10^{-9} \mathrm{M}\right)$, and ascorbate $\left(1 \times 10^{-10} \mathrm{M}\right)$. At pH 3, only EDTA triggers significant increase in the release of $\mathrm{PO}_{4}{ }^{3-}$ (aq) relative to the control (fig. 8). Thus, ligand and phosphate protonation/deprotonation is not the sole parameter controlling mineral dissolution. The concentration of $\mathrm{P}$ released $\left(2.2 \times 10^{-4} \mathrm{M}\right)$ is greater than $\mathrm{Ce}\left(5 \times 10^{-5} \mathrm{M}\right)$ and may be interpreted as the development of a P leached layer at the $\mathrm{CePO}_{4} \cdot \mathrm{H}_{2} \mathrm{O}$-water interface. At $\mathrm{pH} 5$, the dissolution rate of cerium phosphate in the presence of citrate is much faster than that observed in the presence of other ligands and the magnitude of the release $($ at $300 \mathrm{~h})$ of $\mathrm{PO}_{4}{ }^{3-}(\mathrm{aq})$ by citrate $\left(2.7 \times 10^{-4} \mathrm{M}\right)$ is more than twice that induced by oxalate, ascorbate, and humic acids (fig. 6) and is rivaled only by EDTA $\left(1.95 \times 10^{-4} \mathrm{M}\right)$. All of the ligands release two orders of magnitude more phosphate to solution then our model predictions. This result alone seems to preclude congruent dissolution of our starting material at $\mathrm{pH} 5$.

At $\mathrm{pH}$ 8, oxalate promotes the release of $\mathrm{PO}_{4}^{3-}$ (aq) more than citrate or EDTA, with maximum solution concentrations of $\sim 4$ and $\sim 1$ or $1.5 \times 10^{-4} \mathrm{M}$, respectively (fig. 9); humic acids and ascorbate are ineffective at solubilizing cerium phosphate at this $\mathrm{pH}$, possibly because phosphorous stabilization due to the formation of high-molecular weight complexes (Stevenson and Cole, 1999). As with our kinetic studies at lower pH values $\mathrm{P}$ release at $\mathrm{pH} 8$ is notably higher then the predicted concentrations. Particularly with the known soil organic ligands citrate and oxalate it appears that the removal of Ce via secondary mineral formation, a lack of equilibrium conditions and/or the development of extensive leach layers results in a large flux of bioavailable phosphorous into the aqueous phase even under high $\mathrm{pH}$ values.

Data shown in figures 4 through 9 reveal varying concentrations of $\mathrm{PO}_{4}{ }^{3-}{ }_{(\mathrm{aq})}$ in solution with seemingly little correlation to the Ce-ligands stability constants and predicted solubility of $\mathrm{CePO}_{4} \cdot \mathrm{H}_{2} \mathrm{O}$. Considering in some cases (ascorbate, citrate, humic acids, oxalate) Ce concentrations were well below the detection limits of our analytical protocols the incongruent dissolution of $\mathrm{CePO}_{4} \cdot \mathrm{H}_{2} \mathrm{O}$ leads to the unexpectedly high concentrations of phosphate in solution.

\section{CONCLUSIONS}

Oxalate and citrate concentrations in plant cells and tissues can be as high as $1 \mathrm{mM}$ (Madhavi and others, 1996) and concentrations of $<200 \mu \mathrm{M}$ have been reported from soil environments (Fox and Comerford, 1990). Our findings suggest that these and other ligands can promote the dissolution of cerium phosphate, induce the oxidation of $\mathrm{Ce}^{3+}{ }_{(\mathrm{aq})}$, and lead to the formation of $\mathrm{CeO}_{2}$. Perhaps most notable of the results presented here is the lack of correlation between Ce-ligand stability constants and the extent and rates of $\mathrm{Ce}_{(\mathrm{aq})}$ and $\mathrm{PO}_{4}{ }^{3-}{ }_{(\mathrm{aq})}$ release from rhabdophane which precludes the use of current equilibrium based techniques to predict both Ce and $\mathrm{P}$ distribution in the presence of these ligands. Results show that to interpret the interactions between biogenic ligands and $\mathrm{CePO}_{4} \cdot \mathrm{H}_{2} \mathrm{O}$ each ligand must be studied individually and that their unique interactions with may provide important clues about the mechanisms of Ce distribution during chemical weathering and soil formation (Green and others, 2002). Our data add to existing studies (Bingham and Garber, 1960; Bingham, 1963; 
Moore and Reddy, 1994; Moore and others, 1998; Moore, 1999), substantiating the notion that redox-transformations in mineral surfaces may control $\mathrm{PO}_{4}^{3-}(\mathrm{aq})$ and enhance bioavailability in soils and sediments. This experimental work provides evidence of a biologically induced but non-enzymatic pathway for oxidation of $\mathrm{Ce}^{3+}{ }_{(\mathrm{aq})}$ at room temperature. This finding may have broader relevance. The ocean is typically depleted in Ce relative to other lanthanides (a negative Ce anomaly), probably due to precipitation of $\mathrm{CeO}_{2}$ (Henderson, 1984; Braun and others, 1990). Oxidation of $\mathrm{Ce}^{3+}{ }_{(\mathrm{aq})}$ by $\mathrm{O}_{2}$ in seawater is extremely slow, but accelerates in the presence of microorganisms (Moffett, 1990, 1993). Thus, it has been proposed that $\mathrm{Ce}^{3+}{ }_{\text {(aq) }}$ oxidation occurs enzymatically. An alternative explanation, suggested by the current work and research published elsewhere (Cervini-Silva and Banfield, 2003), is that $\mathrm{Ce}^{3+}{ }_{(\mathrm{aq})}$ oxidation is promoted by organic molecules such as catechol, ascorbate, humic acids, and other compounds. Furthermore our work provides an initial step towards developing a conceptual model for the use of laboratory based experimental studies with biogenic ligands to interpret the biological fractionation of Ce in paleosols.

\section{ACKNOWLEDGMENTS}

Support for this research was provided by the NASA Astrobiology Institute (124190 - 31020 - 44) to Javiera Cervini-Silva and Jillian F. Banfield, and a Canada Research Chair Grant to David A. Fowle. We thank Dr. Brian Fryer and Joel Gagnon for help with the ICP-MS analysis. We thank two anonymous reviewers for their useful reviews.

\section{REFERENCES}

Barber, D. A., and Martin, J. K., 1976, Release of organic-substances by cereal roots into soil: New Phytologist, v. 76 , p. $69-80$.

Banfield, J. F., and Eggleton, K., 1989, Apatite replacement and rare earth mobilization, fractionation and fixation during weathering: Clays and Clay Minerals, v. 37, p. 113-127.

Banfield, J. F., Barker, W. W., Welch, S. A., and Taunton, A., 1999, Biological impact on mineral dissolution: application of the lichen model to understanding mineral weathering in the rhyzosphere: Proceedings of the National Academy of Sciences USA, v. 96, p. 3404-3411.

Bendich, A., Machlin, L. J., Scandurra, O., Burton, G. W., and Wayner, D. D. M., 1986, The antioxidant role of vitamin C: Advances in Free Radicals in Biology and Medicine, v. 2, p. 419-444.

Berner, R. A., 1992, Weathering, plants, and the long-term carbon cycle: Geochimica et Cosmochimica Acta, v. 56 , p. $3225-3231$.

Biber, M. V., Afonso, M. D. S., and Stumm, W., 1994, The coordination chemistry of weathering: IV. Inhibition of the dissolution of oxide minerals: Geochimica et Cosmochimica Acta, v. 58, p. 1999-2010

Bingham, F. T., 1963, Relation between P and micronutrients in plants: Soil Science Society America Proceedings, v. 27, p. 389-391.

Bingham, F. T., and Garber, M. J., 1960, Solubility and availability of micronutrients in relation to phosphorous fertilization: Soil Science Society America Proceedings, v. 24, p. 209-213.

Blaser, P., 1994, The role of natural organic matter in the dynamics of metals in forest soils, in Senesi, N., and Miano, T. M., editors, Humic substances in the global environment and implications in human health: Amsterdam, Elsevier, p. 943-960.

Bondietti, G., Sinniger, J., and Stumm, W., 1993, The reactivity of Fe(III) (hydr)oxides: effect of ligands in inhibiting the dissolution: Colloids and Surfaces A: Physicochemical and Engineering Aspects, v. 79, p. $157-167$.

Braun, J. J., Pagel, M., Muller, J. P., Bilong, P., Michard, A., and Guillet, B., 1990, Cerium anomalies in lateritic profiles: Geochimica et Cosmochimica Acta, v. 54, p. 781-795.

Brewster, J. L., Bhat, K. K. S., and Nye, P. H., 1976, The possibility of predicting solute uptake and plant growth response from independently measured soil and plant characteristics. The growth and $\mathrm{P}$ uptake of rape in soil at a range of $\mathrm{P}$ concentrations and a comparison of results with the prediction of a simulation model: Plant and Soil, v. 44, p. 295-328.

Buettner, G. R., 1988, In the absence of catalytic metals ascorbate does not autoxidize at pH 7. Ascorbate as a test for catalytic metals: Journal of Biochemical and Biophysical Methods, v. 16, p. 27-40.

Buettner, G. R., Oberley, L. W., and Leuthauser, S. W. H. C., 1978, The effect of iron on the distribution of superoxide and hydroxyl radicals as seen by spin trapping and on the superoxide dismutase assay: Photochemistry and Photobiology, v. 28, p. 693-695. 
Cervini-Silva, J., and Banfield, J. F., 2003, Catalytic interactions involving cerium, catecholate, and oxygen may be pivotal to phosphorous bioavailability and humic acid production: San Francisco, California, American Geophysical Union Fall Meeting, December 8-12, 2003.

Firsching, F. H., and Brune, S. N. J., 1991, Solubility products of the trivalent rare-earth phosphates: Journal of Chemical Engineering Data, v. 36, p. 93-95.

Fox, T. R., and Comerford, N. B., 1990, Low-molecular weight organic-acids in selected forest soils of the southeastern asia: Soil Science Society America Journal, v. 54, p. 1139-1144.

Gardner, W. K., Barber, D. A., and Parperry, D. G., 1983, The acquisition of phosphorous by Lupinus-albus L.3. The probable mechanism by which phosphorous movement in the soil root interface is enhanced: Plant and Soil, v. 70, p. 107-124.

Gelasco, A., Bensiek, S., and Pecoraro, V. L., 1998, The $\left[\mathrm{Mn}_{2}(2-\mathrm{OH} \text { salpn })_{2}\right]^{2-1-, 0}$ system: An efficient functional model for the reactivity and inactivation of the manganese catalases: Inorganic Chemistry, v. 37, p. 3301-3309.

Green, E. G., Macalady, J. L., and Banfield, J. F., 2002, Biogeochemical contributions to soil formation and landscape lowering: American Geophysical Union, Eos Trans, v. 83(47), Abstract H12B-0929, p. F551.

Henderson, P., editor, 1984, Rare Earth Element Geochemistry: Amsterdam, Elsevier, 510 p.

Hikichi, Y., Hukuo, K. I., and Shiokawa, J., 1978, Synthesis of rare earth orthophosphates: Journal of the Bulletin of the Chemical Society of Japan, v. 51, p. 3645-3646.

Hyun, J. K., Kim, J. S., Kim, S. D., Yoon, H. S., Lee, J. Y., and Kim, W. S, 2002, Ultrasonic study on conglomeration of cerium oxalate particles produced by reaction crystallization in series reactor including T-mixer and stirred tank: Journal of Chemical Engineering of Japan, v. 35, p. 1211-1218.

Ilmer, P. A., Barbato, A., and Schinner, F., 1995, Solubilization of hardly-soluble $\mathrm{AlPO}_{4}$ with P-solubilizing microorganisms: Soil Biology and Biochemistry, v. 27, p. 265-270.

Johnston, C. G., and Vestal, J. R., 1993, Biogeochemistry of oxalate in the antartic cryptoendolithic lichen-dominated community: Microbial Ecology, v. 25, p. 305-319.

Khan, M. M. T., and Martell, A. E., 1967, Metal ion and metal chelate catalysed oxidation of ascorbic acid by molecular oxygen I. Cupric and ferric ion catalysed oxidation: Journal of the American Chemical Society, v. 89, p. 4176-4185.

Kucey, R. M. N., Janzen, H. H., and Leggett, M. E., 1989, Microbially mediated increases in plant available phosphorous: Advances in Agronomy, v. 42, p. 199-228.

Langmuir, D., 1969, The Gibbs free energies of substances in the system $\mathrm{Fe}-\mathrm{O}_{2}-\mathrm{H}_{2} \mathrm{O}-\mathrm{CO}_{2}$ at $25^{\circ} \mathrm{C}$ : U.S. Geological Survey, Professional Paper No. 650 B, p. 180-184.

Larson, R. A., 1998, Naturally Occurring Antioxidants: Boca Raton, CRC Lewis Press, 195 p.

Lasaga, A. C., 1994, Kinetic Theory in the Earth Sciences: Princeton, Princeton University Press, 811 p.

Leyval, C., and Berhelin, J., 1989, Interactions between laccaria-laccata, agrobacterium-radiobacter and beech rootsInfluence on P, K, Mg, and Fe mobilization from minerals and plant growth: Plant and Soil, v. 117, p. 103-110. 1991, Weathering of a mica by roots and rhyzospheric microorganisms of pine: Soil Science Society America Journal, v. 55, p. 1009-1016.

Madhavi, D. L., Singhal, R. S., and Kulkarni, P. R., 1996, Technological aspects of food antioxidants, in Madhavi, D. L., Deshpande, S. S., and Salunkhe, D. K., editors, Food antioxidants: technological, toxicological, and health perspectives: New York, Marcel Dekker, p. 159-265.

Magers, K. D., Smith, C. G., and Sawyer, D. T., 1978, Polarographic and spectroscopic studies of the manganese(II), -(III), and -(IV) complexes formed by polyhydroxy ligands: Inorganic Chemistry, v. 17 , p. 515-523.

Martell, A. E., 1982, Chelates of ascorbic acid formation and catalytic properties, in Seib, P. A., and Tolbert, B. M., editors, Ascorbic acid, chemistry, metabolism, and uses: Washington, D. C., American Chemical Society, p. 124-178.

Martell, A. E., and Smith, R. M., 1972, Critical Stability Constants volume 3: Other Ligands: New York, Plenum Press, $473 \mathrm{p}$.

McKeague, J. A., Cheshire, M. V., Andreux, F., and Berthelin, J., 1986, Organic-mineral complexes in relation to pedogenesis, in Huang, P. M., and Schnitzer, M., editors, Interactions of soil minerals with natural organics and microbes: Madison, Soil Science Society America, p. 549-592.

Moffett, J. W., 1990, Microbially mediated cerium oxidation in seawater: Nature, v. 345, p. 421-423.

_ 1993, A radiotracer study of cerium and manganese uptake on to suspended particles in Chesapeake Bay: Geochimica et Cosmochimica Acta, v. 58, p. 695-703.

Moore, P. A., 1999, Effect of redox potential on phosphorous chemistry in soils and sediments: Fort Lauderdale, Florida, Sixth Symposium on Biogeochemistry of Wetlands, July 11-14, 1999, p. 130.

Moore, P. A., and Reddy, K. R., 1994, Role of Eh and $\mathrm{pH}$ on phosphorous geochemistry in sediments of Lake Okeechobee, Florida: Journal of Environmental Quality, v. 23, p. 955-964.

Moore, P. A., Reddy, K. R., and Fisher, M. M., 1998, Phosphorous flux between sediment and overlying water in Lake Okeechobee, Florida: Spatial and temporal variations: Journal of the Environmental Quality, v. 27, p. 1428-1439.

Morrison, M. M., and Sawyer, D. T., 1977, Redox reactions of di- $\mu$-oxo bridged binuclear manganese(IV) and -(III) complexes: Journal of the American Chemical Society, v. 99, p. 257-258

Nye, P. H., 1977, The rate limiting step in plant nutrient absorption from the soil: Soil Science. v. 123, p. 292-297.

1979, Soil properties controlling the supply of nutrients to the root surface, in Harley, J. L., and Scott Russell, R., editors, The soil-root interface: New York, Academic Press, p. 39-49.

Ochs, M., 1996, Influence of humified and non-humified natural organic compounds on mineral dissolution: Chemical Geology, v. 132, p. 119-124.

Pierpont, C. R., and Buchanan, R. M., 1981, Transition metal complexes of $o$-benzoquinone, $o$-semiquinone, and catecholate ligands: Coordination Chemistry Reviews, v. 38, p. 45-87. 
Pouchert, C. J., 1997, The Aldrich Library of FT-IR Spectra: Milwaukee, Aldrich Chemical Company.

Sheriff, T. S., 1992, Production of hydrogen-peroxide from dioxygen and hydroxylamine or hydrazine catalyzed by manganese complexes: Journal of the Chemical Society Dalton Transactions, v. 6, p. 1051-1058.

Sillen, L. G., 1971, Stability Constants of Metal-Ion Complexes: London, Chemical Society, Special Publication No. 17,865 p.

Sofen, S. R., Cooper, S. R., and Raymond, K. N., 1979, Crystal and molecular structures of tetrakis (catecholato) hafnate(IV) and -cerate(IV). Further evidence for a ligand field effect in the structure of tetrakis (catecholate) uranate(IV): Inorganic Chemistry, v. 18, p. 1611-1616.

Sposito, G., 1994, Chemical Equilibria and Kinetics in Soils: New York, Oxford University Press, 268 p.

Stevenson, F. J., and Cole, M. A., 1999, Cycles of Soils: Carbon, Nitrogen, Phosphorus, Sulfur, and Micronutrients: New York, John Wiley and Sons, $421 \mathrm{p}$.

Stumm, W., and Morgan, J., 1996, Aquatic Chemistry: New York, Wiley-Interscience, 1022 p.

Stumm, B., Wehrli, E., and Wieland, E., 1987, Surface complexation and its impact on geochemical kinetics: Croatica Chimica Acta, v. 60, p. 429-456.

Tan, K. H., 1980, The release of silicon, aluminum, and potassium during decomposition of soil minerals by humic acid: Soil Science, v. 129, p. 5-11.

Taunton, A. E., Welch, S. A., and Banfield, J. F., 2000, Geomicrobiological controls on light rare earth element, Y and Ba distribution during granite weathering and soil formation: Journal of Alloys Compounds, v. 303-304, p. 30-36.

Trolard, F., and Tardy, Y., 1987, The stabilities of gibbsite, boehmite, aluminous goethites and aluminous hematites in bauxites, ferricretes and laterites as a function of water activity, temperature and particle-size: Geochimica et Cosmochimica Acta, v. 51, p. 945-957.

Ushakov, S. V., Helean, K. B., Navtrosky, A., and Boatner, L. A., 2001, Thermochemistry of rare-earth orthophosphates: Journal of Materials Research, v. 16, p. 2623-2633.

Uusitalo, R., and Turtola, E., 2003, Determination of redox-sensitive phosphorous in field runoff without sediment preconcentration: Journal of the Environmental Quality, v. 32, p. 70-77.

Van der Lee, J., 1998, Thermodynamic and mathematical concepts of CHESS. LHM/RD/98/39, CIG-Ecole des Mines de Paris Fontainebleau: France.

Welch, S. A., and Ullman, W. J., 1992, Dissolution of feldspars in oxalic acid solutions, in Kharaka, Y. K., and Maest, A. S., editors, Proceedings of the $7^{\text {th }}$ water rock interaction meeting, Park City, Utah (13-17 July, 1992): Rotterdam, A. A., Balkema, p. 127-130.

- 1996, Feldspars dissolution in acidic and organic solutions: Compositional and $\mathrm{pH}$ dependence of dissolution rate: Geochimica et Cosmochimica Acta, v. 60, p. 2939-2948.

Welch, S. A., Barker, W. W., and Banfield, J. F., 1999, Microbial extracellular polysaccharides and plagioclase dissolution: Geochimica et Cosmochimica Acta, v. 63, p.1405-1419.

Xu, H., Gao, L., Gu, H., Guo, J., and Yan, D., 2002, Synthesis of solid, spherical $\mathrm{CeO}_{2}$ particles prepared by the spray hydrolysis reaction method: Journal of the American Ceramic Society, v. 85, p. 139-144. 